\title{
Effect of Different Organic Fertilizers on the Growth Performance of Corchorus olitorius $\mathrm{L}$.
}

\author{
Ayeni, M.J' ${ }^{1}$. Oye, O.V ${ }^{2}$. \\ ${ }^{1}$ (Department of Plant Science andBiotechnology, Ekiti State University, PMB 5363 Ado- Ekiti, Ekiti State \\ Nigeria) \\ ${ }^{2}$ (Department of Plant Science andBiotechnology, Ekiti State University, PMB 5363 Ado- Ekiti, Ekiti State \\ Nigeria)
}

\begin{abstract}
The effects of three kinds of organic fertilizers were examined on the growth performance of Corchorusolitorius L. The experiment was laid in Completely Randomized Design (CRD) with four treatments.

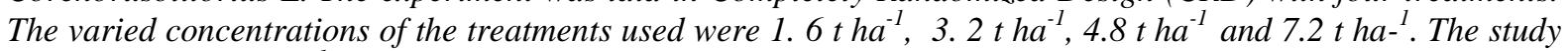
revealed that $7.2 t$ ha $a^{-1}$ of poultry manure produced the highest growth at 8 weeks after transplanting (8WAT). Goat manure at $7.2 \mathrm{t} \mathrm{ha-}{ }^{1}$ had the highest number of leaves while poultry manure has the least number of leaves. Poultry manure at $7.2 \mathrm{th} \mathrm{a}^{-1}$ produced the highest number of branches. This was similar to those of goat and cowdung manure treated pots. Goat manure at $7.2 \mathrm{t} \mathrm{ha}^{-1}$ treated pots produced the highest leaf area and stem girth. C. olitorius flowered earlier at higher concentration of poultry manure $\left(7.2\right.$ tha $\left.a^{-1}\right)$ in 26 days which was similar to goat manure treated seedlings at $3.2 \mathrm{tha}^{-1}$ that flowered in 29 days. The highest biomass of $C$. olitorius occurred mostly in goat manure treated seedlings. Statistical analysis (ANOVA, $P<0.05)$ showed that significant differences were observed in the leaf area of cowdung treated seeds, stem girth of goat manure, days to flowering of poultry manure and cowdung, dry root biomass of poultry and cowdung with dry shoot of cowdung. Also, significant differences were observed on the height of C. olitorius at 4WAT to 8WAT in treated pots when compared to the control experiment. It was observed that the three types of fertilizers increased the growth parameters of C. olitorius in all the parameters studied but best growth occurred in goat manure treated plants. It is suggested that all the organic fertilizers under study should be a good option in the cultivation of this vegetable as they are cheaper to procure.
\end{abstract}

Keywords: Organic, poultry manure, cowdung, goat manure, Corchorus olitorius

\section{Introduction}

Soil nutrient depletion has been on the increase due to continuous cropping and deforestation. Deforestation resulted in soil erosion and reduction in soil mineral nutrients. The loss in essential nutrients required for optimum growth of crop caused food insecurity (Senjobi, 2007). Ogbona (2008) noted that one of the major problems limiting crop production is soil fertility. Hamadem and Fadni (2010) reported that low soil fertility as one of the main factors for the low production of vegetables. Mojeremaneet al. (2015) noted that the productivity of many African soils is normally limited by Nitrogen and Phosphorus which are the major constraints to small holder vegetable producers in sub-sahara Africa.

The quest for improvement of soil fertility led to the use of inorganic fertilizers to improve crop production. Oroka (2012) noted that depleted soil need to be ameliorated with fertilizers to increase growth and yield of crops and vegetables. Shiman and Binang (2011) reported that the high cost of inorganic fertilizers make it undesirable and uneconomical to the resource poor farmers who dominated the Nigerian Agricultural sector. Ojeniyiet al. (2009) reported the use of inorganic fertilizer to increase the yield of crops have been found to be effective as a short term solution which demands consistence use on a long term basis. Also, Masarimbiet al. (2011) noted that the uses of inorganic fertilizers in combination with organic materials are able to give the desired and sustainable crop yields than the sole use of inorganic fertilizers.

Adequate fertilization of the soil is needed to maximize the yield of leafy vegetables through the use of organic fertilizers. Tovihoudjiet al. (2015) noted that organic waste could be viable alternative to chemical fertilizers as organic farming has the long term productivity in soil conservation and improvement in soil fertility for sustainable food security. Besides, researchers such as Adejuyigbeet al. (2012), Alabadanet al. (2009) and Dikinya and Mufwanzala (2010) reported that organic fertilizers improve soil moisture, increased soil organic matter, Nitrogen, pH, phosphorus and Cation Exchange Capacity (CEC) and reduced exchangeable acidity.

C. olitorius is one of the indigenous vegetable which is important in human diet especially in poor communities. Indigenous vegetables are more nutritious and relatively cheaper than the exotic species (Madisaet al., 2013). C. olitorius play an important role in nutrition and household food security (Tovihoudjiet al., 2015). It is mostly cultivated by women in south western Nigeria. The leaves of $C$. olitorius were reported 
to be a rich source of protein, vitamins and mineral (Tindall, 1983, Dentol and Gruben, 2004). The leaves are cooked into thick viscous soap added to stews and eaten with starch stapes (Asoegwu and Ibitoye, 1983). It is an important fibre for making sacks and carpets (Chandrase- Karan et al., 2010).

Apart from the nutritional values of $C$. olitorius, Obohet al.(2009) reported that the leafy vegetables such as $C$. olitorius is popularly used in soap preparation and folk medicine for the for the treatment of fever, chronic cystitis, cold and tumours. Shittu and Ogunmoyela (2001) reported that the young shoot tips of $C$. olitorius can be eaten raw or cooked and it contains high level of protein and vitamin C. Oyedele et al. (2006) reported that $C$. olitorius is usually recommended for pregnant women and nursing mothers because it is believed to be rich in iron. C. olitorius(Jute mallow) responds well to fertilization particularly nitrogen (Ogunrinde and Fasinmirin, 2011). This crop is mostly planted by the resource poor farmers. Most of these farmers cannot afford to purchase inorganic fertilizers due to their poor income.

Alternative sources of fertilizers that are cheaper, eco-friendly and capable of enhancing sustainable crop production is advocated. This involves the use of natural organic fertilizers. The study is carried out to investigate the growth performance andyield of $C$. olitorius as influenced by organic fertilizers.

\section{Materials And Methods}

The experiment was carried out at the experimental site of the Department of Plant Science and Biotechnology, Ekiti State University, Ado-Ekiti, Nigeria ( $7^{\circ} 37^{\prime} \mathrm{N}$ and Longitude $5^{\circ} 13^{\prime} \mathrm{E}$ ). The experiment was carried out between December 2015 to March 2016. Seeds of Corchorusolitorius were collected from Oba's market at IlaweEkiti in Ekiti South West local Government area of Ekiti State.

Cultivated soil was obtained on campus, air dried for 2 weeks and sieved through a $5 \mathrm{~mm}$ mesh. Equal amount of soil $(5 \mathrm{~kg})$ was measured with weighing balance and were put in planting pots and replicated five times per treatment. Routine analysis was carried out and the soil was analysed to be sandy clay loam with soil organic matter of $1.85 \%, 0.3 \% \mathrm{~N}, 6.15 \mathrm{mgkg}^{-1} \mathrm{P}$ and $0.48 \mathrm{mgkg}^{-1}$, with a $\mathrm{pH}$ of 5.53 .

The treatments included three organic fertilizers (Poultry manure, cowdung and goat manure). Cowdung and poultry manure were obtained from Teaching and Research Farm, Faculty of Agricultural Sciences, Ekiti State University, Ado-Ekiti. Goat manure was obtained from homesteads in Ado - Ekiti, a town about $4 \mathrm{~km}$ from Ekiti State University Campus. The organic fertilizers were also analysed. Poultry manure was analysed to have $2.50 \% \mathrm{~N}, 7.71 \mathrm{mgkg}-{ }^{1} \mathrm{P}$ and $6.73 \mathrm{mgkg}-{ }^{1} \mathrm{~K}$ with $\mathrm{pH}$ of 7.52 . Cowdung was analysed to have $2.19 \% \mathrm{~N}, 3.48 \mathrm{mgkg}_{-}{ }^{1} \mathrm{P}, 6.36 \mathrm{mgkg}-{ }^{1} \mathrm{~K}$ with $\mathrm{pH}$ of 8.20 . Likewise, goat manure was analysed to have $2.30 \% \mathrm{~N}$, $4.36 \mathrm{mgkg}_{-}{ }^{1} \mathrm{P}, 3.53 \mathrm{mgkg}_{-}{ }^{1} \mathrm{~K}$ and $\mathrm{pH}$ of 7.54 .

The treatments were varied into different concentrations $\left(1.6,2.4,4.8,7.2 \mathrm{t} \mathrm{ha-}^{-1}\right)$ and replicated four times. The treatments were mixed with the soil two weeks before transplanting for mineralization. The seedlings had earlier stayed in the nursery for two weeks. The pot experiments were laid down in a Completely Randomized Design (CRD) with the treatment replicated 4 times. A control experiment without any manure was also set up and replicated 4 times. The parameters assessed were weekly height, number of leaves, number of branches, stem girth, number of fruits and leaf area was determined according to Kayode and Tedela (2005) as : $\mathrm{A}=\mathrm{L} \times \mathrm{B} \times 0.75$ where $\mathrm{A}=$ length of the leaf, $\mathrm{B}=$ breadth the leaf and $0.75=$ constant

The data collected from the experiments were subjected to statistical analysis using Analysis of Variance (ANOVA) and Duncan Multiple Range Test (DMRT) was used to separate the means.

\section{Results}

Effects of organic fertilizers on the height $(\mathrm{cm})$ of $C$. olitorius

The effects of organic fertilizers on the weekly height of $C$. olitorius are shown in Table 1 . The result revealed that $C$. olitorius heights obtained in $7.2 \mathrm{ha}^{-1}$ of poultry manure was the highest at 8 weeks after transplanting $(52.28 \mathrm{~cm})$. The control experiment had the shortest plants $(10.38 \mathrm{~cm})$. Statistical analysis (ANOVA, $\mathrm{P}<0.05$ ) showed the initial height of $C$. olitorius were not significantly different to the control experiment. At 8WAT, significant differences were observed in the treated plants compared to the control.

Table1: Effects of organic fertilizers on the height $(\mathrm{cm})$ of C.olitorius

\begin{tabular}{|l|l|l|l|l|l|}
\hline \multirow{2}{*}{$\begin{array}{l}\text { Treatment } \\
\left(\text { tha }^{-1}\right)\end{array}$} & Initial height & \multicolumn{4}{|c|}{6} \\
\cline { 3 - 6 } & & 2 & \multicolumn{4}{|c|}{8} \\
\hline PM 0 & $2.37 \pm 0.15^{\mathrm{a}}$ & $3.50 \pm 0.34^{\mathrm{a}}$ & $5.43 \pm 0.78^{\mathrm{b}}$ & $7.45 \pm 2.35^{\mathrm{b}}$ & $10.38 \pm 3.59^{\mathrm{b}}$ \\
\hline PM 1.6 & $2.65 \pm 0.79^{\mathrm{a}}$ & $5.98 \pm 0.93^{\mathrm{a}}$ & $17.28 \pm 6.29^{\mathrm{a}}$ & $28.55 \pm 19.42^{\mathrm{a}}$ & $33.85 \pm 22.94^{\mathrm{a}}$ \\
\hline PM 3.2 & $2.75 \pm 0.38^{\mathrm{a}}$ & $6.15 \pm 2.25^{\mathrm{a}}$ & $18.98 \pm 4.32^{\mathrm{a}}$ & $32.28 \pm 4.24^{\mathrm{a}}$ & $37.30 \pm 6.42^{\mathrm{a}}$ \\
\hline PM 4.8 & $2.15 \pm 0.17^{\mathrm{a}}$ & $6.43 \pm 0.97^{\mathrm{a}}$ & $21.18 \pm 1.51^{\mathrm{a}}$ & $38.58 \pm 1.52^{\mathrm{a}}$ & $43.50 \pm 1.61^{\mathrm{a}}$ \\
\hline PM 7.2 & $2.53 \pm 0.36^{\mathrm{a}}$ & $5.78 \pm 0.95^{\mathrm{a}}$ & $21.55 \pm 4.58^{\mathrm{a}}$ & $48.20 \pm 18.93^{\mathrm{a}}$ & $52.28 \pm 18.94^{\mathrm{a}}$ \\
\hline GM 1.6 & $2.93 \pm 0.75^{\mathrm{a}}$ & $7.55 \pm 2.22^{\mathrm{a}}$ & $19.83 \pm 3.59^{\mathrm{a}}$ & $34.00 \pm 6.43^{\mathrm{a}}$ & $38.50 \pm 6.73^{\mathrm{a}}$ \\
\hline GM 3.2 & $2.95 \pm 0.37^{\mathrm{a}}$ & $5.40 \pm 0.96^{\mathrm{a}}$ & $22.38 \pm 4.33^{\mathrm{a}}$ & $35.93 \pm 6.25^{\mathrm{a}}$ & $40.08 \pm 7.29^{\mathrm{a}}$ \\
\hline GM 4.8 & $2.43 \pm 0.31^{\mathrm{a}}$ & $4.95 \pm 1.50^{\mathrm{a}}$ & $19.95 \pm 5.17^{\mathrm{a}}$ & $38.08 \pm 6.14^{\mathrm{a}}$ & $41.50 \pm 6.29^{\mathrm{a}}$ \\
\hline GM 7.2 & $2.45 \pm 0.73^{\mathrm{a}}$ & $6.98 \pm 2.92^{\mathrm{a}}$ & $25.50 \pm 5.15^{\mathrm{a}}$ & $43.90 \pm 6.19^{\mathrm{a}}$ & $47.55 \pm 6.80^{\mathrm{a}}$ \\
\hline
\end{tabular}


Effect Of Different Organic Fertilizers On The Growth Performance Of Corchorus Olitorius L.

\begin{tabular}{|l|l|l|l|l|l|}
\hline CD 1.6 & $2.25 \pm 0.34^{\mathrm{a}}$ & $4.30 \pm 0.64^{\mathrm{a}}$ & $13.43 \pm 1.31^{\mathrm{a}}$ & $25.58 \pm 1.58^{\mathrm{a}}$ & $31.23 \pm 2.38^{\mathrm{a}}$ \\
\hline CD 3.2 & $1.93 \pm 0.48^{\mathrm{a}}$ & $3.95 \pm 0.44^{\mathrm{a}}$ & $13.28 \pm 4.82^{\mathrm{a}}$ & $27.05 \pm 5.61^{\mathrm{a}}$ & $33.40 \pm 8.46^{\mathrm{a}}$ \\
\hline CD 4.8 & $2.30 \pm 0.85^{\mathrm{a}}$ & $4.35 \pm 0.88^{\mathrm{a}}$ & $18.45 \pm 2.55^{\mathrm{a}}$ & $28.90 \pm 7.93^{\mathrm{a}}$ & $34.63 \pm 9.23^{\mathrm{a}}$ \\
\hline CD 7.2 & $2.45 \pm 0.82^{\mathrm{a}}$ & $5.18 \pm 1.81^{\mathrm{a}}$ & $17.40 \pm 3.47^{\mathrm{a}}$ & $29.55 \pm 3.06^{\mathrm{a}}$ & $36.18 \pm 6.06^{\mathrm{a}}$ \\
\hline
\end{tabular}

Means followed by the same letter within column of the same treatment are not significantly difference at $(\mathrm{P}<$ $0.05)$.

$\mathrm{PM}=$ Poultry manure, $\mathrm{GM}=$ Goat manure, $\mathrm{CD}=\mathrm{Cow}$ dung, $\mathrm{WAT}=$ Week after transplanting.

\section{Effects of organic fertilizers on the number of leaves of $C$. olitorius}

The effects of organic fertilizers on the mean number of leaves are presented in Table 2 . It was observed that the highest mean number of leaves at 8 WAT occurred in goat manure (159.72) at $7.2 \mathrm{t} \mathrm{ha}^{-1}$ concentration. The number of leaves in the treatments was higher than the control experiment. Significant differences were observed in the number of leaves of treated plants when compared to the control experiment at $5 \%$ level of significance.

Table 2: Effects of organic fertilizers on the mean number of leaves of $C$. olitorius

\begin{tabular}{|c|c|c|c|c|c|}
\hline \multirow{2}{*}{$\begin{array}{l}\text { Treatment } \\
\left(\text { tha }^{-1}\right)\end{array}$} & \multirow{2}{*}{$\begin{array}{l}\text { Initial number of } \\
\text { leaves. }\end{array}$} & \multicolumn{4}{|c|}{ Weeks After Transplanting ( WAT) } \\
\hline & & 2 & 4 & & \\
\hline PM 0 & $6.75 \pm 0.50^{\mathrm{a}}$ & $8.00 \pm 0.82^{\mathrm{c}}$ & $11.50 \pm 3.00^{\mathrm{f}}$ & $27.75 \pm 10.56^{\mathrm{f}}$ & $47.75 \pm 26.31^{\mathrm{f}}$ \\
\hline PM 1.6 & $4.75 \pm 1.26^{\mathrm{a}}$ & $16.50 \pm 4.65^{b}$ & $53.00 \pm 35.86^{\mathrm{e}}$ & $78.00 \pm 53.71^{\mathrm{e}}$ & $99.25 \pm 66.35^{\mathrm{e}}$ \\
\hline PM 3.2 & $5.75 \pm 0.50^{\mathrm{a}}$ & $17.00 \pm 8.83^{b}$ & $50.75 \pm 7.80^{\mathrm{e}}$ & $82.75 \pm 20.90^{\mathrm{de}}$ & $111.25 \pm 27.80^{\mathrm{d}}$ \\
\hline PM 4.8 & $4.75 \pm 0.50^{\mathrm{a}}$ & $12.25 \pm 4.03^{\mathrm{c}}$ & $59.50 \pm 12.79^{\mathrm{de}}$ & $87.25 \pm 11.87^{\mathrm{d}}$ & $115.50 \pm 15.59^{\mathrm{d}}$ \\
\hline PM 7.2 & $5.50 \pm 0.58^{\mathrm{a}}$ & $20.50 \pm 4.03^{\mathrm{a}}$ & $60.50 \pm 8.19^{\mathrm{cd}}$ & $105.50 \pm 12.87^{\mathrm{ab}}$ & $136.75 \pm 21.08^{\mathrm{b}}$ \\
\hline GM 1.6 & $5.50 \pm 0.58^{\mathrm{a}}$ & $14.50 \pm 7.59^{b}$ & $68.75 \pm 5.50^{c}$ & $89.50 \pm 8.74^{\mathrm{cd}}$ & $125.25 \pm 13.87^{\mathrm{c}}$ \\
\hline GM 3.2 & $5.75 \pm 1.26^{\mathrm{a}}$ & $21.50 \pm 7.94^{\mathrm{a}}$ & $79.00 \pm 18.92^{b}$ & $98.00 \pm 18.06^{\mathrm{bc}}$ & $135.25 \pm 22.94^{\mathrm{b}}$ \\
\hline GM 4.8 & $4.50 \pm 1.29^{\mathrm{a}}$ & $20.25 \pm 4.99^{\mathrm{a}}$ & $95.25 \pm 30.99^{\mathrm{a}}$ & $112.00 \pm 31.44^{\mathrm{a}}$ & $143.25 \pm 32.08^{b}$ \\
\hline GM 7.2 & $5.25 \pm 0.96^{\mathrm{a}}$ & $26.50 \pm 8.69^{\mathrm{a}}$ & $105.25 \pm 17.25^{\mathrm{a}}$ & $119.25 \pm 13.28^{\mathrm{a}}$ & $159.75 \pm 18.93^{\mathrm{a}}$ \\
\hline CD 1.6 & $4.75 \pm 0.50^{\mathrm{ab}}$ & $8.75 \pm 3.30^{\mathrm{c}}$ & $65.25 \pm 23.13^{\mathrm{c}}$ & $94.25 \pm 8.88^{c}$ & $125.00 \pm 14.51^{\mathrm{c}}$ \\
\hline CD 3.2 & $4.75 \pm 0.50^{\mathrm{ab}}$ & $10.50 \pm 5.92^{\mathrm{c}}$ & $61.75 \pm 22.69^{\mathrm{cd}}$ & $95.75 \pm 25.25^{\mathrm{c}}$ & $130.50 \pm 20.89^{b}$ \\
\hline CD 4.8 & $4.25 \pm 0.50^{\mathrm{b}}$ & $10.75 \pm 4.03^{\mathrm{c}}$ & $53.00 \pm 22.42^{\mathrm{e}}$ & $86.00 \pm 20.94^{\mathrm{d}}$ & $132.50 \pm 15.93^{b}$ \\
\hline CWD 7.2 & $5.50 \pm 0.58^{\mathrm{a}}$ & $15.50 \pm 7.51^{b}$ & $73.50 \pm 13.17 b$ & $102.50 \pm 23.69^{b}$ & $139.25 \pm 29.18^{b}$ \\
\hline
\end{tabular}

Means followed by the same letter within column of the same treatment are not significantly difference at $(\mathrm{P}<0.05)$.

$\mathrm{PM}=$ Poultry manure, $\mathrm{GM}=$ Goat manure, $\mathrm{CD}=\mathrm{Cow}$ dung, WAT $=$ Week after transplanting.

\section{Effects of organic fertilizers on the number of branches of $\boldsymbol{C}$. olitorius}

The effects of organic fertilizers on the number of branches are shown in Table 3 . The number of branches at 8WAT was highest in poultry manure (18.25) at $7.2 \mathrm{t} \mathrm{ha}^{-1}$. The number of branches of the three treatments at 8WAT was higher than that of the control experiment. No significant difference was observed in the number of branches except in the control experiment which gave the lowest number of branches at $5 \%$ level.

Table 3: Effects of organic fertilizers on the mean number of branches of C.olitorius

\begin{tabular}{|c|c|c|c|c|c|}
\hline \multirow{2}{*}{$\begin{array}{l}\text { Treatment } \\
\left(\text { tha }^{-1}\right)\end{array}$} & \multirow{2}{*}{$\begin{array}{l}\text { Initial no of } \\
\text { branches }\end{array}$} & \multicolumn{3}{|c|}{ Weeks After Transplanting ( WAT) } & \\
\hline & & 2 & 4 & 6 & \\
\hline PM 0 & $0.00 \pm 0.00^{\mathrm{a}}$ & $0.00 \pm 0.00^{\mathrm{c}}$ & $1.25 \pm 2.50^{\mathrm{b}}$ & $2.00 \pm 3.37^{\mathrm{b}}$ & $3.75 \pm 3.05^{\mathrm{b}}$ \\
\hline PM 1.6 & $0.00 \pm 0.00^{\mathrm{a}}$ & $5.50 \pm 4.20^{\mathrm{ab}}$ & $6.00 \pm 4.24^{\mathrm{a}}$ & $10.00 \pm 7.48^{\mathrm{a}}$ & $14.50 \pm 9.82^{\mathrm{a}}$ \\
\hline PM 3.2 & $0.00 \pm 0.00^{\mathrm{a}}$ & $5.75 \pm 2.22^{\mathrm{ab}}$ & $9.00 \pm 1.83^{\mathrm{a}}$ & $12.50 \pm 3.32^{\mathrm{a}}$ & $14.75 \pm 3.59^{\mathrm{a}}$ \\
\hline PM 4.8 & $0.00 \pm 0.00^{\mathrm{a}}$ & $8.25 \pm 1.26^{\mathrm{a}}$ & $9.00 \pm 1.83^{\mathrm{a}}$ & $10.50 \pm 2.08^{\mathrm{a}}$ & $15.00 \pm 3.56^{\mathrm{a}}$ \\
\hline PM 7.2 & $0.00 \pm 0.00^{\mathrm{a}}$ & $7.00 \pm 0.82^{\mathrm{a}}$ & $9.75 \pm 0.50^{\mathrm{a}}$ & $13.25 \pm 1.89^{\mathrm{a}}$ & $18.25 \pm 2.87^{\mathrm{a}}$ \\
\hline GM 1.6 & $0.00 \pm 0.00^{\mathrm{a}}$ & $5.25 \pm 0.96^{b}$ & $10.00 \pm 1.41^{\mathrm{a}}$ & $12.75 \pm 3.09^{\mathrm{a}}$ & $14.75 \pm 3.59^{\mathrm{a}}$ \\
\hline GM 3.2 & $0.00 \pm 0.00^{\mathrm{a}}$ & $6.00 \pm 1.63^{\mathrm{b}}$ & $9.50 \pm 0.58^{\mathrm{a}}$ & $14.50 \pm 1.73^{\mathrm{a}}$ & $16.50 \pm 1.73^{\mathrm{a}}$ \\
\hline GM 4.8 & $0.00 \pm 0.00^{\mathrm{a}}$ & $8.50 \pm 1.73^{\mathrm{a}}$ & $10.50 \pm 0.58^{\mathrm{a}}$ & $13.25 \pm 1.50^{\mathrm{a}}$ & $17.00 \pm 2.83^{\mathrm{a}}$ \\
\hline GM 7.2 & $0.00 \pm 0.00^{\mathrm{a}}$ & $7.00 \pm 1.41^{\mathrm{ab}}$ & $10.50 \pm 0.58^{\mathrm{a}}$ & $12.00 \pm 2.45^{\mathrm{a}}$ & $17.25 \pm 3.77^{\mathrm{a}}$ \\
\hline CD 1.6 & $0.00 \pm 0.00^{\mathrm{a}}$ & $3.50 \pm 0.58^{\mathrm{bc}}$ & $5.75 \pm 1.50^{\mathrm{a}}$ & $10.00 \pm 0.82^{\mathrm{a}}$ & $13.75 \pm 3.09^{\mathrm{a}}$ \\
\hline CD 3.2 & $0.00 \pm 0.00^{\mathrm{a}}$ & $3.75 \pm 2.50^{\mathrm{bc}}$ & $6.50 \pm 2.52^{\mathrm{a}}$ & $10.25 \pm 1.26^{\mathrm{a}}$ & $14.25 \pm 2.87^{\mathrm{a}}$ \\
\hline CD 4.8 & $0.00 \pm 0.00^{\mathrm{a}}$ & $4.25 \pm 1.50^{\mathrm{ab}}$ & $7.25 \pm 2.22^{\mathrm{a}}$ & $10.50 \pm 2.08^{\mathrm{a}}$ & $14.25 \pm 2.06^{\mathrm{a}}$ \\
\hline CD 7.2 & $0.00 \pm 0.00^{\mathrm{a}}$ & $5.25 \pm 1.89^{\mathrm{ab}}$ & $7.50 \pm 1.29^{\mathrm{a}}$ & $12.50 \pm 2.52^{\mathrm{a}}$ & $15.75 \pm 3.30^{\mathrm{a}}$ \\
\hline
\end{tabular}

Means followed by the same letter within column of the same treatment are not significantly different at $(\mathrm{p}<0.05)$.

$\mathrm{PM}=$ Poultry manure, $\mathrm{GM}=$ Goat manure, $\mathrm{CD}=\mathrm{Cow}$ dung, WAT $=$ Week after transplanting.

\section{Effects of organic fertilizers on the leaf area $\left(\mathrm{cm}^{2}\right)$ and stem girth at harvest of $C$. olitorious}

The effects of organic fertilizers on the leaf area $\left(\mathrm{cm}^{2}\right)$ and stem girth at harvest were shown in Table 4. The highest leaf area recorded was in goat manure $\left(52.25 \mathrm{~cm}^{2}\right)$ at $7.2 \mathrm{t} \mathrm{ha}^{-1}$ followed by cowdung manure $(49.68 \mathrm{~cm})$ at $7.2 \mathrm{t} \mathrm{ha}^{-1}$. The leaf area of goat manure and cowdung treated plants were higher than those of 
poultry manure. The control experiments had the least leaf area $\left(16.23 \mathrm{~cm}^{2}\right)$. Significant differences were observed in the leaf area of the treated plants compared to the control experiment at $5 \%$ level of significance.

Goat manure produced the highest stem girth $(2.30 \mathrm{~cm})$ at $7.2 \mathrm{t} \mathrm{ha}^{-1 .}$ Stem girth in poultry and cowdung manures were similar while the control experiment had the least girth $(0.70 \mathrm{~cm})$. Significant differences were observed in the stem girth of treated plants compared to the control experiment.

Table 4: Effects of organic fertilizers on the mean leaf area and stem girth at harvest of C.olitorius

\begin{tabular}{|c|c|c|}
\hline Treatment $\left(\right.$ tha $\left.^{-1}\right)$ & Leaf area $\left(\mathrm{cm}^{2}\right)$ at $8 \mathrm{WAT}$ & Stem girth $(\mathrm{cm})$ at $8 \mathrm{WAT}$ \\
\hline PM 0 & $16.23 \pm 8.47^{\circ}$ & $0.70 \pm 0.14^{\mathrm{d}}$ \\
\hline PM 1.6 & $35.70 \pm 24.11^{b}$ & $1.28 \pm 0.54^{\mathrm{c}}$ \\
\hline PM 3.2 & $35.98 \pm 8.14^{b}$ & $1.50 \pm 1.02^{\mathrm{bc}}$ \\
\hline PM 4.8 & $44.15 \pm 8.75^{\mathrm{a}}$ & $1.68 \pm 0.17^{\mathrm{ab}}$ \\
\hline PM 7.2 & $45.70 \pm 12.03^{\mathrm{a}}$ & $1.85 \pm 0.26^{b}$ \\
\hline GM 1.6 & $41.10 \pm 3.52^{\mathrm{a}}$ & $1.75 \pm 0.24^{\mathrm{b}}$ \\
\hline GM 3.2 & $41.53 \pm 10.11^{\mathrm{a}}$ & $2.05 \pm 0.13^{\mathrm{ab}}$ \\
\hline GM 4.8 & $43.73 \pm 4.95^{\mathrm{a}}$ & $2.20 \pm 0.50^{\mathrm{a}}$ \\
\hline GM 7.2 & $52.73 \pm 14.51^{\mathrm{a}}$ & $2.30 \pm 0.28^{\mathrm{a}}$ \\
\hline CWD 1.6 & $34.05 \pm 5.48^{\mathrm{b}}$ & $1.25 \pm 0.17^{\mathrm{c}}$ \\
\hline CWD 3.2 & $35.98 \pm 6.93^{\mathrm{b}}$ & $1.40 \pm 0.22^{\mathrm{bc}}$ \\
\hline CWD 4.8 & $39.40 \pm 4.93^{\mathrm{b}}$ & $1.70 \pm 0.27^{\mathrm{ab}}$ \\
\hline CWD 7.2 & $49.48 \pm 12.66^{\mathrm{a}}$ & $1.80 \pm 0.24^{b}$ \\
\hline
\end{tabular}

Means followed by the same letter within column of the same treatment are not significantly difference at $(\mathrm{P}<0.05)$.

$\mathrm{PM}=$ Poultry manure, $\mathrm{GM}=$ Goat manure, $\mathrm{CD}=\mathrm{Cow}$ dung, WAT $=$ Week after transplanting.

Effects of organic fertilizers on the days to flowering and number of fruits of $\boldsymbol{C}$. olitorius

The effects of organic fertilizers on the days to flowering after transplanting and number of fruits at harvest were shown in Table 5. Poultry manure treated plants flowered early (26 days) after transplanting at $7.2 \mathrm{t} \mathrm{ha}^{1}{ }^{-1}$ which was similar to that of goat manure treated plants that flowered at 29 days after transplanting at $3.2 \mathrm{t} \mathrm{ha}^{-1}$, but $1.6 \mathrm{t} \mathrm{ha}^{-1}$ of cowdung flowered at 35 days after transplanting. Significant differences were observed in the days to flowering of treated plants when compared to the control experiment. Goat and cowdung manure treated plants produced similar number of fruits with the highest number of fruits (22) in $7.2 \mathrm{t} \mathrm{ha}^{-1}$ concentration. The three variants showed significant differences in the number of leaves when compared to the control experiment.

Table 5. Effects of organic fertilizers on the days to flowering and mean number of fruits at harvest of C.olitorius

\begin{tabular}{|l|l|l|}
\hline Treatment $\left(\right.$ tha $\left.^{-1}\right)$ & Days to flowering & Number of fruit at harvest. \\
\hline PM 0 & $17.25 \pm 2.36^{\mathrm{b}}$ & $3.25 \pm 0.50^{\mathrm{b}}$ \\
\hline PM 1.6 & $30.25 \pm 4.50^{\mathrm{a}}$ & $12.00 \pm 9.83^{\mathrm{a}}$ \\
\hline PM 3.2 & $37.00 \pm 0.00^{\mathrm{a}}$ & $18.00 \pm 4.24^{\mathrm{a}}$ \\
\hline PM 4.8 & $32.50 \pm 5.19^{\mathrm{a}}$ & $18.25 \pm 2.99^{\mathrm{a}}$ \\
\hline PM 7.2 & $26.25 \pm 18.23^{\mathrm{a}}$ & $19.25 \pm 7.41^{\mathrm{a}}$ \\
\hline GM 1.6 & $31.50 \pm 4.36^{\mathrm{a}}$ & $12.50 \pm 6.61^{\mathrm{a}}$ \\
\hline GM 3.2 & $29.00 \pm 10.86^{\mathrm{a}}$ & $13.75 \pm 10.14^{\mathrm{a}}$ \\
\hline GM 4.8 & $36.00 \pm 2.00^{\mathrm{a}}$ & $15.00 \pm 6.78^{\mathrm{a}}$ \\
\hline GM 7.2 & $34.75 \pm 4.50^{\mathrm{a}}$ & $22.00 \pm 6.78^{\mathrm{a}}$ \\
\hline CWD 1.6 & $35.75 \pm 5.50^{\mathrm{a}}$ & $12.50 \pm 6.61^{\mathrm{a}}$ \\
\hline CWD 3.2 & $37.00 \pm 0.00^{\mathrm{a}}$ & $13.75 \pm 10.14^{\mathrm{a}}$ \\
\hline CWD 4.8 & $37.25 \pm 6.18^{\mathrm{a}}$ & $15.00 \pm 6.78^{\mathrm{a}}$ \\
\hline CWD 7.2 & $37.75 \pm 1.50^{\mathrm{a}}$ & $22.00 \pm 6.78^{\mathrm{a}}$ \\
\hline
\end{tabular}

Means followed by the same letter within column of the same treatment are not significantly different at $(\mathrm{P}<0.05)$.

$\mathrm{PM}=$ Poultry manure, $\mathrm{GM}=$ Goat manure, $\mathrm{CD}=\mathrm{Cow}$ dung, WAT = Week after transplanting.

\section{Effects of organic fertilizers on the biomass of $C$. olitorius}

The effects of organic fertilizers on the biomass of $C$. olitorius are shown in Table 6. Poultry manure at $7.2 \mathrm{t} \mathrm{ha}^{-1}$ produced the highest fresh root weight $(2.46 \mathrm{~g})$. Goat manure at $7.2 \mathrm{t} \mathrm{ha}^{-1}$ had the highest fresh root weight $(43.63 \mathrm{~g})$. Cowdung treated plants at $7.2 \mathrm{t} \mathrm{ha}^{-1}$ produced the highest dry root and shoot biomass $(1.55 \mathrm{~g}$ and $10.38 \mathrm{~g}$ ) respectively. Significant differences were observed in the fresh and dry root and shoot weights of treated plants when compared to the control experiment. 
Table 6: Effects of organic fertilizers on the fresh and dry biomass ( $\mathrm{g}$ ) of root and shoot of C.olitorius

\begin{tabular}{|l|l|l|l|l|}
\hline Treatment $\left(\mathrm{t} \mathrm{ha}^{-1}\right)$ & Fresh root biomass & Fresh shoot biomass & Dry root biomass & Dry shoot biomass \\
\hline PM 0 & $0.28 \pm 0.96^{\mathrm{b}}$ & $0.78 \pm 0.96^{\mathrm{b}}$ & $0.07 \pm 0.01^{\mathrm{c}}$ & $0.38 \pm 0.05^{\mathrm{g}}$ \\
\hline PM 1.6 & $1.58 \pm 1.28^{\mathrm{a}}$ & $21.63 \pm 14.64^{\mathrm{a}}$ & $0.78 \pm 0.52^{\mathrm{b}}$ & $5.88 \pm 4.00^{\mathrm{ef}}$ \\
\hline PM 3.2 & $1.80 \pm 0.49^{\mathrm{a}}$ & $22.80 \pm 4.54^{\mathrm{a}}$ & $0.85 \pm 0.21^{\mathrm{b}}$ & $6.05 \pm 1.20^{\text {def }}$ \\
\hline PM 4.8 & $2.46 \pm 1.58^{\mathrm{a}}$ & $27.78 \pm 4.91^{\mathrm{a}}$ & $0.88 \pm 0.19^{\mathrm{b}}$ & $7.18 \pm 0.79^{\text {cde }}$ \\
\hline PM 7.2 & $3.23 \pm 0.49^{\mathrm{a}}$ & $31.20 \pm 5.44^{\mathrm{a}}$ & $1.45 \pm 0.30^{\mathrm{a}}$ & $7.70 \pm 1.81^{\text {cde }}$ \\
\hline GM 1.6 & $1.63 \pm 0.55^{\mathrm{a}}$ & $26.35 \pm 4.26^{\mathrm{a}}$ & $0.70 \pm 0.82^{\mathrm{b}}$ & $8.45 \pm 1.19^{\mathrm{bc}}$ \\
\hline GM 3.2 & $1.93 \pm 1.03^{\mathrm{a}}$ & $30.43 \pm 9.21^{\mathrm{a}}$ & $0.78 \pm 0.13^{\mathrm{b}}$ & $9.02 \pm 1.38^{\mathrm{bc}}$ \\
\hline GM 4.8 & $2.30 \pm 1.15^{\mathrm{a}}$ & $35.48 \pm 1.95^{\mathrm{a}}$ & $1.43 \pm 0.32^{\mathrm{a}}$ & $12.98 \pm 1.40^{\mathrm{a}}$ \\
\hline GM 7.2 & $2.40 \pm 0.65^{\mathrm{a}}$ & $43.63 \pm 22.65^{\mathrm{a}}$ & $1.53 \pm 0.81^{\mathrm{a}}$ & $13.25 \pm 7.18^{\mathrm{a}}$ \\
\hline CD 1.6 & $1.50 \pm 0.42^{\mathrm{a}}$ & $26.43 \pm 12.99^{\mathrm{a}}$ & $0.65 \pm 0.13^{\mathrm{b}}$ & $4.43 \pm 1.15^{\mathrm{f}}$ \\
\hline CD 3.2 & $1.68 \pm 0.17^{\mathrm{a}}$ & $21.10 \pm 3.13^{\mathrm{a}}$ & $0.80 \pm 0.26^{\mathrm{b}}$ & $4.83 \pm 1.59^{\mathrm{f}}$ \\
\hline CD 7.2 & $2.30 \pm 3.56^{\mathrm{a}}$ & $33.33 \pm 8.22^{\mathrm{a}}$ & $0.88 \pm 0.25^{\mathrm{b}}$ & $6.10 \pm 0.49^{\mathrm{d}}$ \\
\hline
\end{tabular}

Means followed by the same letter within column of the same treatment are not significantly different at $(\mathrm{P}<$ $0.05)$.

$\mathrm{PM}=$ Poultry manure, $\mathrm{GM}=$ Goat manure, $\mathrm{CD}=\mathrm{Cow}$ dung, WAT = Week after transplanting.

\section{Discussion}

\section{Effects of organic fertilizers on the height $(\mathrm{cm})$ of $C$. olitorius}

The results of this study showed that the tallest plants, highest number of leaves and early flowering were observed in poultry manure treated plants. This might be attributed to the nitrogen concentration provided by poultry manure that resulted in the increase of the vegetative growth of $C$. olitorius. This was in accordance with the work of Adenawoola and Adejoro (2005) who found that poultry manure increased the growth and yield of C. olitorius. Kogbe and Adediran (2003) and Ayeniet al. (2016) reported that poultry manure contain nitrogen which led to increase in maize performance. Also, Senjobiet al. (2013) noted that poultry manure produced the highest value in plant height and stem girth of $C$ oiltorius. Marti et al. (2004) noted that adequate supply of nitrogen is associated with vigorous vegetative growth resulting from high photosynthetic activities. Nitrogen is very important for photosynthetic activity and vegetative growth. Previous study by Kavanovaet al. (2008) asserted that nitrogen deficiency severely reduced leaf blade growth by increasing cell cycle duration and decreasing mitotic and post mitotic rates.

\section{Effects of organic fertilizers on the number of leaves of $C$. olitorius}

The highest number of leaves of $C$. olitorius was recorded in goat manure at $7.2 \mathrm{t} \mathrm{ha}^{-1}$. The result might be attributed to the release of nitrogen from goat manure that brought high vegetative growth by producing more buds. This is in line with the work of Madisaet al. (2013) that good performance of C. olitorius was shown by treatment with sole chicken manure. Masarirambiet al. (2012) noted that the highest number of leaves was obtained from lettuce supplied with 60 tha $^{-1}$ chicken manure. The role of nitrogen in promoting vigorous vegetative growth in leafy vegetables was reported by Tovihoudjiet al. (2015) Tisdale and Nelson (1996). The increase in the number of leaves and yield was due to increased solubilisation effect and availability of nutrients by the addition of organic manures relatively results in better development of more leaves (Tovihoudjiet al., 2015). Opeyemi and Adegboyega (2003) noted that animal manure increased number of leaves, stem girth and leaf length of C. olitorus.

\section{Effects of organic fertilizers on the number of branches of $C$. olitorius}

Poultry manure treated plants produced the highest number of branches which is directly proportional to increase in the number of leaves of $C$. olitorius. This corroborated Ullahet al. (2008) who observed that the application of organic fertilizer and nitrogen fertilizers solely or combined had a great influence on the vegetative growth of crops. Ademiluyi and Fabiyi (2015) had earlier reported that higher performance in poultry manure on growth of maize might be attributed to the improved soil tilt, aeration, water holding capacity and stimulation of microorganisms in the soil which makes the nutrients available.

\section{Effects of organic fertilizers on the leaf area $\left(\mathrm{cm}^{2}\right)$ and stem girth at harvest of $C$. olitorious}

The study showed that goat manure had the highest leaf area and stem girth than cowdung and poultry manure. This might be attributed the fact that the decomposition of goat manure enhanced the mineralization of nutrients in the soil. This was in accordance with the work of Ibewuchiet al. (2006) who reported that organic manure increase nutrient status of the soil through gradual release of nutrients to the soil. Agbede et al. (2008) reported that organic manure increases nitrogen, phosphorus and potassium content of the soil. Likewise Olanikan (2006) noted that organic manure increase organic matter status of the soil and enhance crop production. 


\section{Effects of organic fertilizers on the biomass of $C$. olitorius}

The highest fresh root and shoot weights were shown in goat and cowdung manures. This report lends credence to the work of Schippers (2000) who noted that the used manures significantly influence the vegetative yield of C. olitorius. Said (1997) reported that the addition of organic manures increase the plant growth characteristics such as plant height, number of leaves and shoot per plant including fresh root and shoot weights. Also, Aluko (2014) reported that the overall performance of $C$. olitorius at $8 \mathrm{WAP}$ showed that the plant treated with fertilizers have thicker stem, more leaves and higher dry matter than unfertilized plants.

\section{Conclusion}

The findings from this study showed that soil amended with the three organic fertilizersimprove the growth and yield performance of $C$. olitorious. This suggests that any of the three manures (poultry, cowdung and goat manures) might be a good option for the cultivation of $C$. olitorious by the resource poor farmers as it is cheaper, readily available and environmental friendly.

\section{References}

[1]. Adediran, O.A., Ibrahim, H., Tolorunse, K.D. and Gana, U.I. (2015). Growth, Yield and Quality of Jute Mallow (Corchorusolitorius L.) as affected by different Nutrient Sources. International Journal of Agriculture Innovations and Research.3(5): 2319-1473.

[2]. Adejuyigbe, C.O., Adesodun, J.K., Harris, P., Aiyelaagbe, I.O.O. (2012). Potential ofon farm produced compost and organic amendments in soil fertility management oforganic maize production in South Western Nigeria. Archives of Agronomy and Soil Science. 58(1): 170-174.

[3]. Ademiluyi, B.O. and Fabiyi, E.S. (2015). Response of Hybrid Maize (Zea mays) to organic and inorganic fertilizers in soils of South -West and North Central Nigeria. International Journal of Plant and Soil Science. 7(2): 121-127.

[4]. Adenaeoola, A.R. and Adejoro, S.A. (2005). Residual effects of poultry manure and NPK Fertilizer residues on soil nutrient and performance of Jute (CorchorusolitoriusL.). Nigerian Journal of Soil Science. 15: 133-135.

[5]. Adeniyan, O.N. and combination of the reduced levels on maize growth and soil chemical properties. Nigeria Journal of Soil Science 15:34-41.

[6]. Agbede, T.M., Ojeniyi, S.O. and Adeyemo, A.J. (2008). Effect of organic manure on soil physical and chemical properties, growth and grain yield of sorghum in south western Nigeria. Ame- Eurasian J. SustainableAgric., 2(1): 72-77.

[7]. Alabadan, B.A., Adeoye, P.A., Folorunsho, E.A. (2009). Effect of different poultry wastes on physical, chemical and biological properties of Soil. Caspian J. Environ. Sci. 7(1): 31-35.

[8]. Aluko, O.A., Olanipekun, T.O., Olasoji, J.O., Abiola, I.O., Adeniyan, O.N.,Olanipekun, S.O., Omenna, E.C., Kareem, K.O. and Douglas, A.I. (2014). Effect of Organic and Inorganic Fertilizers on the yield and Nutrient composition of Jute Mallow.Global Journal of Agricultural Research. 2(3): 1-9.

[9]. Ayeni, M.J., Ademiluyi, B.O. and Shittu, R.A. (2016) Effects of organic and inorganic fertilizers on the growth performance of Solanumnigrum L. Journal of Agriculture and Ecology Research. 5(4):1-6.

[10]. Chandrasekaran, B., Annadurai, K and Somasundaram, E. (2010). A textbook of Agronomy. New Age International Publishers, New Delhi. 835pp.

[11]. Dinkinya, O. and Mufwanzala, N. (2010). Chicken manure enhanced soil fertility and productivity. Effects of application rates. Journal of soil Science and Environment Management. 1(3): 46-54.

[12]. Grubben, G. J.H and Dentol, O.A. (2004). Plant Resources of Tropical Africa 2. Vegetables. PROTA Foundation. Wageningen, Netherlands $\backslash$ Backkhuys Publishers, Leinden, Netherlands ICTA Wageningen Netherlands. Pp. 552-556.

[13]. Gungula, D.T., Togun, A.O. and Kings, J.G. (2005). The influence of N rates on maize leaf number and senescence in Nigeria. World Journal of Agricultural Science. 1: 01-05.

[14]. Hamdem, M.I.K. and Fadni, O.E. (2010). Effect of Different Types of Organic Fertilizers on Growth Quality and Yield of Tomatoes in Sandy Soil. Agricultural Research Corporation. Second RU FORUM Biennial Meeting 20-24 $4^{\text {th }}$ September 2010. Entebbe Uganda.

[15]. Husselman, M. AndSizane, N.I. (2006). A guide to the use of wild leafy vegetables in Eastern Cape Grahams town. Rhodes University South Africa.

[16]. Ibeawuchi, I.I., Onwerenmadu, E.U. and On, N.N. (2006). Effect of poultry manure on green (Amaranthuscruentus) and water leaf (Talinumtriangulare) on degraded utisols of Owerri South Eastern Nigeria. J. Anim. Vet. Adv., 5(1): 53-56.

[17]. Kavanova, M., Latanzi, F.A., and Schnyder, H. (2008). Nitrogen deficiency inhibits leaf blade growth in Lliumperenne by increasing cell cycle duration and decreasing mitotic and post mitotic growth rates. Plant cell Environ. 31(6): 727-737.

[18]. Kogbe, J.O.S. and Adediran, J.A. (2003). Influence of Nitrogen, Phosphorus and Potassium application on the yield of maize in savannah zones of Nigeria. African Journal of Biotechnology. 2(10): 245-239.

[19]. Madisa, M.E., Mathowa, T., Mfofu, C., Stephen, Na. and Machacha, S. (2013). Effect of chicken manure and commercial fertilizer on performance of jute Mallow (Corchorusolitorus). Agriculture and Biology Journal of North America 4(6): 617-622.

[20]. Marti, A.R. and Millis, H. A. (1991). Nutrient Uptake and yield of Sweet pepper as affected by stage of development and N. form. J. Plant Nutri. 14(11): 165-175.

[21]. Masarirambi, M.T., Diamini, P., Wahome, P.K. and Oseni, T.O. (2012). Effects of chicken manure on growth and yield Quality of Lettuce (Lactucasativa L.). Tianaunder a Lath house in a semi- Arid Sub- tropical Environment. American Eurasian J. Agric. And Environment Sci., 12: 399-406.

[22]. Masarirambi, M.T., Sibandze, N., Wahome, P.K and Oseni, T.O. (2001). Effect of Chicken Manure Application Rates on Growth and Yield of Wild Okra (Cochorusolitorus L. in a sub-tropical Environment. Asian Journal of Agricultural Science. 4:89-95.

[23]. Mojeremane, W., Motladi, M., Mathowa, T. and Legwaila, G.M. (2015). Effect of Different Application Rates of Organic Fertilizer on Growth, Development and Yield of Rape (Brassica napus L.). International Journal of Innovative Research in Science, Engineering and Technology. 4(12): 11680-111688.

[24]. Najm, A.A., Hadi, M.R.H.S., Fazeli, F. Darz, M.T. and Rahi, A. (2012). Effect of integrated management of Nitrogen Fertilizer and cattle manure on the leaf chlorophyll. Yield and Tuber Glycoalkaloids of Agric potato. Communications of soil Science and plant Analysis. 43(6): 912-923. 
[25]. Oboh, G., Radata, H. and Henle, T. (2009). Characterization of the antioxidant properties of hydrophilic and lipophilic extract of Jute (Corchoriusolitorius) leaf. International Journal of Food Sciences and Nutrition. 60: 124-134.

[26]. Ogunrinde, A.T. and Fasimirin, J.T. (2011). Soil moisture Distribution pattern and yield of Jute mallow (CorchorusolitoriusL.). under Three Different Soil Fertility Management. Proceeding of the Environmental Management Conference. Federal university of Agriculture Abeokuta Nigeria.

[27]. Ojeniyi, S.O, Owolabi, O., Akinola, O.M and Odedina, S.A. 2009. Field study of effect of organomineral fertilizer on maize growth yield Soil and Plant nutrient composition in Ilesa. South West Nigeria. Nigeria Journal of Soil Science 19:11-16.

[28]. Olanikan, P.C.(2006). Organic manure as soil amendments in eroded tropical soil of south western Nigeria. J. Trop. Soil. 5(3): 1118.

[29]. Omisoore, J.K., Kasail, M.Y. and Chukwu, U.C. (2009). Determination of optimum poultry manure rate for maize production. Proceedings of the $43^{\text {rd }}$ Annual Conference of the Agricultural Society of Nigeria, Abuja, 43: 260-263.

[30]. Opeyemi, S.O. and Adegboyega, A.A. (2003). To investigate the separate and combined effect of urea and goat dung on leaf nutrient contents, growth and yield of Celosia argentea in south western Nigeria. Niger. Agric. J., 34: 87-90.

[31]. Oroka, F.O. (2012). Comparative effects of Muniapa solid waste compost and NPK fertilizer on the growth and marketable yield of Celosia argentea. New York Science Journal. 5(10): 34-38.

[32]. Oyedele, D.J., Asonugho, C. and Awotoye, O.O. (2006). Heavy metals in soil and accumulated by edible vegetable after phosphate fertilizer application. Electron Journal of Environmental and Agricultural Foo Chemistry. 54(4): 1446 - 1453.

[33]. Said, A.H. (1997). Influence of some organic fertilizers on the growth and yield of pepper plants (Capsicum annum L.) cultivated under plastic houses. MSc. Thesis, Fac. Agric., Ainshams Univ. Egypt.

[34]. Schippers, R.R. (2000). African indigenous vegetables. An Overview of the cultivated species. University Greenwich England. Pp193-205.

[35]. Senjobi, B.A. (2013). Sandy soil Improvement Using Organic materials and mineral fertilizers on the yield and Quality of Jute Plant (Corchorusolitorius). Journal of Biology and Life Science. 4(1): 219-233.

[36]. Shittu, T.A. and Ogunmoyela, O.A. (2001). Water balancing treatment and nutrient retention in some Nigerian green leafy vegetables. Proceedings $25^{\text {th }}$ ed. Pp. 20.

[37]. Shiyam, J.O. and Biang, W.B. (2011)." Effects of poultry manure and Urea-n on flowering occurrence and leaf productivity of Amaranthuscruentus". Journal of Applied Sciences and Environmental Management. 15(1): 13-15.

[38]. Tovihoudji, G.P., Djogbenou, C.P., Akponikpe, P.B.I., Kpadonou, E., Agbanga, C.E. and Dagbenonbakin, D.G. (2015). Response of Jute Mallow (Corchorusolitorius L.) to organic manure and inorganic fertilizer on a ferruginous soil in North Eastern Benin. J. Applied Bio Science. 92: 8610-8619.

[39]. Trindall, H.D. (1983). Vegetables in the tropics. ELBS/ Macmillan Hongkong 326 and 393.

[40]. Ullah, M.S., Islam, M.S., Isalam, M.A. and Haque, T. (2008). Effects of organic manures and chemical fertilizers on the yield of Brinjal and soil properties. J. Bangladesh Agric. Univ., 6: 271-276. 